\title{
SUICÍDIO SIMBÓLICO
}

\section{Causou frisson, no primeiro semestre deste} ano, o anúncio de que a Foxconn, maior fabricante mundial de componentes eletrônicos, pretende passar a fabricar produtos da Apple aqui no Brasil. De fato, a notícia tem seu lado positivo: é importante para o país diversificar a sua pauta de produção e exportações, ainda mais tratando-se de produtos de alta tecnologia. Os empregos e os investimentos diretos e indiretos gerados pela criação de uma fábrica desse porte são muito relevantes. Pensar na criação de um parque tecnológico associado ao investimento da Foxconn, em que se coloque o país na vanguarda do desenvolvimento de tecnologias para o futuro, pode ter benefícios econômicos extremamente proveitosos.

Porém, a Foxconn possui algumas histórias muito pouco gloriosas, que merecem ser explicadas de maneira mais detalhada. Em maio de 2010, a imprensa internacional divulgou um fato alarmante: vários empregados da empresa haviam cometido suicídio, e outros tinham sido encontrados mortos de ataque cardíaco, dentro dos alojamentos da fábrica chinesa. Tais mortes teriam sido catalisadas pelas precárias condições de trabalho na empresa. Organizações não governamentais que monitoram a questão naquele país denunciaram que a fábrica da Foxconn é gerida com um estilo militar e que o trabalho segue uma rígida postura. Posteriormente, um jornalista da agência internacional de notícias Reuters chegou a ser agredido por seguranças da empresa, ao tentar fotografar a fábrica chinesa, que, vista de fora, mais parece uma fortaleza. Um repórter chinês conseguiu se infiltrar na fábrica e revelou que o estresse dos funcionários, tanto mental quanto físico, era extremo. Revelou-se, ainda, que a empresa paga salários muito baixos, ao mesmo tempo em que força os empregados a fazer horas extras além dos limites legais. É proibido conversar na linha de produção, pode-se ir ao banheiro apenas 10 minutos a cada duas horas, e todos os funcionários passam por revistas rigorosas para entrar e sair da fábrica.

Para vir ao Brasil, essa mesma empresa exigiu do governo uma série de contrapartidas em termos de benefícios fiscais e infraestrutura. A opinião pública brasileira parece muito feliz com o fato de que alguns de seus maiores objetos de desejo, os produtos da Apple, serão fabricados em Pindorama, mas parece não estar muito preocupada com a vinda ao Brasil de uma empresa com essa cultura e esse currículo. É claro que as leis trabalhistas no Brasil são muito mais rigorosas e mais bem aplicadas do que na China. Também não há dúvidas de que o suicídio é uma decisão individual. Porém, ao colocar seus trabalhadores sob condições de trabalho extenuantes e degradantes, uma empresa tem graves responsabilidades pelas mortes que aconteceram dentro dos seus muros.

O caso da Foxconn é extremo e absurdo, mas, mesmo assim, escancara algo muito mais frequente no mundo corporativo contemporâneo do que pensamos. Embora haja todo um discurso valorizando a participação e o bem-estar dos empregados, as organizações insistem em, na prática, forçar as pessoas a trabalharem demasiadamente, comprometendo outros aspectos de suas vidas. Já há bastante tempo vemos executivos trabalhando 10, 12 ou mesmo 14 horas por dia. O trabalho passa a ser a vida das pessoas, e isso produz o suicídio simbólico de quem só vive para ele. O mundo corporativo precisa fazer com que o discurso de respeito pelas pessoas se transforme em uma realidade.
"O trabalho passa a ser a vida das pessoas, e isso produz o suicídio simbólico de quem só vive para ele"

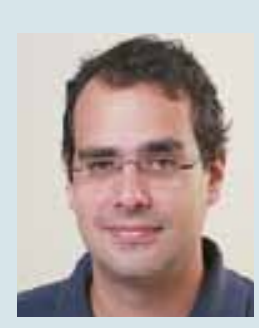

RAFAEL ALCADIPANI, FGV-EAESP

rafael.alcadipani@fgv.br 